\title{
Variability of Ha-ras (codon 12) proto-oncogene mutations in diverse thyroid cancers
}

\author{
Mourad Bouras ${ }^{1,2}$, Jacques Bertholon ${ }^{2}$, Nicole Dutrieux-Berger ${ }^{3}$, Parviz Parvaz ${ }^{1,2}$, Christian Paulin $^{4}$ and \\ André Revol ${ }^{1,2}$ \\ ${ }^{1}$ Laboratoire de Biologie Moléculaire et Pédiatrique, Centre Hospitalier Lyon-Sud, Bât. 3B, 69475 Pierre-Bénite Cedex, France , ${ }^{2}$ Laboratoire de \\ Biochimie Endocrinienne et Moléculaire. Institut des Sciences Pharmaceutiques et Biologiques, 8 avenue Rockefeller, 69373 Lyon Cedex O8, France, \\ ${ }^{3}$ Laboratoire d'Anatomopathologie, Hôpital de l'Hôtel-Dieu, place de l'Hôpital, 69288 Lyon Cedex 02, France and ${ }^{4}$ Laboratoire de Cytologie, Centre \\ Hospitalier Lyon-Sud, Bât 1G, 69475 Pierre-Bénite Cedex, France
}

(Correspondence should be addressed to A Revol, Laboratoire de Biochimie Endocrinienne et Moléculaire, Faculté de Pharmacie de Lyon, 8 Avenue Rockefeller, 69373 Lyon Cedex 08, France)

\begin{abstract}
Structural alterations to proto-oncogene sequences may be involved in the pathogenesis of human thyroid neoplasms. We studied 128 thyroid tumours ( 35 benign and 93 malignant) for ras gene point mutations in three different codons $(12,13$ and 61$)$ using a restriction fragment length polymorphism technique and direct sequencing of double-stranded DNA on polymerase chain-reaction-amplified tumour DNA. We found a high frequency of ras mutation for the Ha-ras codon 12 in follicular adenomas ( 7 of 35), particularly in atypical adenomas ( 5 of 17), in follicular carcinomas (6 of 19), with a high percentage for Hürthle cell carcinomas (6 of 11), and in papillary carcinomas (4 of 66). Point mutations for other ras genes in different codons studied were weak to absent. No mutation was found in undifferentiated carcinomas $(n=8)$. The predominant amino acid substitution both in the adenomas and in the differentiated tumours was glycine to valine (GGC to GTC) at position 12 of the Ha-ras gene.

Our results obtained on a large series confirm the frequent occurrence of Ha-ras codon 12 gene mutations both in adenomas and in carcinomas. The frequency of ras mutations is linked to the geographical origin of the population studied, and varies $(0-85 \%)$ from one cancer type to another according to published data. Therefore, these mutations are merely an expression of cellular transformation.
\end{abstract}

European Journal of Endocrinology 139 209-216

\section{Introduction}

The ras proto-oncogenes (Ha-, Ki-, and N-ras) are believed to have an important role (1) in the genesis of human cancer. Mutations at codons 12, 13 or 61 of ras proto-oncogenes are found in more than $30 \%$ of human tumours (2). A mutation in one allele is sufficient to convert the genes into active oncogenes (1).

At present, it is important to identify new biological markers, the presence of which in precancerous lesions could predict the risk of development of cancer. Studies of various types of benign and malignant thyroid tumours have revealed the presence of activated ras oncogenes in some of them (3-7). Although the number of tumours included in each study was relatively small, it appears that mutations in ras genes are frequent in thyroid tumours, and can affect all three ras genes. Lemoine et al. (4) have found an association between the frequency of ras activation observed in follicular and papillary carcinomas and the biological behaviour and progression of the tumour (8).
In this work, we have studied the frequency of ras gene mutations in 'hot' codons (frequently mutated) (12, 13 and 61), using a greater number of benign and malignant tumours and applying sensitive and specific techniques. We analysed 128 thyroid tumours: adenomas $(n=35)$, and follicular $(n=19)$, papillary $(n=66)$ and undifferentiated carcinomas $(n=8)$. When a mutation was observed, it was identified by a sequencing technique.

The results show a high frequency of Ha-ras codon 12 mutation in atypical adenomas and Hürthle cell carcinomas compared with a low frequency in papillary carcinomas and a complete absence of mutations in undifferentiated carcinomas. For the other ras genes, the frequency of ras mutations was low to nil.

Codon 12 Ha-ras gene mutation may participate in the processes of transformation and progression of thyroid tumours. However, cellular malignant transformation requires the association of several gene anomalies, including the activation of some (trk and ret) and the mutation of tumour suppressor genes (p53 and Rb). 
Table 1 Histological classification of different thyroid tissues studied.

\begin{tabular}{lr}
\hline Adenomas & \\
Atypical & 17 \\
Macrofollicular & 2 \\
Microfollicular & 5 \\
Normofollicular & 7 \\
Toxic & 4 \\
Carcinomas & \\
Papillary & 66 \\
Follicular & 19 \\
Undifferentiated & 8 \\
Total & 128 \\
\hline
\end{tabular}

\section{Materials and methods}

\section{Tissues}

Human normal and tumorous thyroid tissues, identified according to the World Health Organization (WHO) histological classification of thyroid tumours (9), were provided by the Department of Pathology, Services of the Lyon-Sud Hospital Centre and Antiquaille Hospital. Samples were taken from 128 patients after total or partial thyroidectomy. The tumours included 35 adenomas and 93 carcinomas (Table 1). Pathological samples and samples of normal tissue (ten patients) from sites remote from the lesion were immediately frozen in liquid nitrogen and kept at $-70^{\circ} \mathrm{C}$.

\section{Primers and probes}

Oligonucleotides were synthesized by Genset (Genset Oligos, Paris, France). We used oligonucleotides encoding PCR primers, and wild-type or mutated ras sequences around codons 12, 13 and 61, described by Jiang et al. (10).

The sequence corresponding to nucleotides $1872-$ 1892 (5'-CTGCATGGTGCTGTGGCCCT-3') was used as a probe for Southern blot analysis of Ha-ras codon 12 gene. The oligonucleotide primers for nested-PCR of Ha-ras codon 12 gene were: 5'-GACGGAATATAAGCTGGTGG-3' (exon 1: 1671-1691), 5'-CTGCTTATGCTGTGGTGATATCT-3' (exon 1: 1779-1757). For the sequencing of Ha-ras codon 12 gene, one primer of the nested-PCR set primer was used.

\section{Nucleic acid extraction}

Several samples from the same pathological tissue were used for DNA extraction. About $40 \mathrm{mg}$ tissue was ground twice in $0.5 \mathrm{ml}$ lysis buffer $(0.2 \mathrm{~mol} / \mathrm{l}$ Tris- $\mathrm{HCl}$, pH $7.5 ; 20 \mathrm{mmol} / \mathrm{l} \mathrm{EDTA;} 0.3 \mathrm{~mol} / \mathrm{l} \mathrm{NaCl})$. The ground tissue was incubated overnight in a $50{ }^{\circ} \mathrm{C}$ water bath with $2 \%$ SDS and $9 \mathrm{U}$ proteinase $\mathrm{K}$ (Amresco, Solon, $\mathrm{OH}$, USA).
DNA isolation was performed with two phenolchloroform-isoamylalcohol (25:24:1) extractions (Amresco), followed by two chloroform-isoamylalcohol (24:1) extractions. Ammonium acetate (final concentration, $2 \mathrm{~mol} / \mathrm{l}$ ) was added to the aqueous layer, which was then ethanol precipitated. DNA was pelleted, air dried, and resuspended in water. After quantification by absorption at $260 \mathrm{~nm}$, extracts were stored at $-20^{\circ} \mathrm{C}$ until required for assay.

\section{PCR amplification of thyroid tissue DNA}

The amplification was performed according to a modification of the technique of Jiang et al. (10). Genomic DNA $(1 \mu \mathrm{g})$ was amplified for 30 cycles with 2.5 U Taq DNA polymerase (Promega Corp., Madison, WI, USA) and $1 \mu \mathrm{mol} / \mathrm{l}$ of each oligonucleotide primer, in a total volume of $50 \mu \mathrm{l}$.

For DNA amplification, the sample was first denatured at $94^{\circ} \mathrm{C}$ for $10 \mathrm{~min}$ and then rapidly chilled in an ice bath before amplification in a Hybaid Thermalcycler (Hybaid, Ceralabo, Aubervilliers, France) $\left(94^{\circ} \mathrm{C}\right.$ for $1 \mathrm{~min}, 56{ }^{\circ} \mathrm{C}$ for $2 \mathrm{~min}$ and $72{ }^{\circ} \mathrm{C}$ for $3 \mathrm{~min}$ ). Each PCR experiment included a negative control with distilled water in place of DNA and a positive control DNA, extracted from peripheral blood leucocytes of normal individuals. After completion of PCR, $15 \mu \mathrm{l}$ of the PCR product was analysed on $2 \%$ agarose (Tébu FMC, Rockland, ME, USA) gel electrophoresis in $1 \times \mathrm{TBE}$ buffer $(45 \mathrm{mmol} / \mathrm{l}$ Tris-borate; $1 \mathrm{mmol} / \mathrm{l}$ EDTA, $\mathrm{pH}$ 8.0) and visualized, after ethidium bromide staining, under u.v. light. The HaeIII digest of $\Phi$ X174 (Sigma) was used as molecular size marker.

\section{Detection of mutations after DNA enzyme digestion}

The experiments were performed according to modifications of the techniques of Scott et al. (10). One microlitre digestion buffer $(10 \times)(10 \mathrm{mmol} / \mathrm{l}$ Tris-HCl, $\mathrm{pH} 7.5$; $10 \mathrm{mmol} / \mathrm{l} \mathrm{MgCl} 2 ; 1 \mathrm{mmol} / \mathrm{l}$ dithiothreitol) was added to $10 \mu \mathrm{l}$ amplified products and incubated with $2 \mu \mathrm{l}$ restriction enzyme (MspI) overnight at $37^{\circ} \mathrm{C}$. After this digestion, gel electrophoresis in a $4 \%$ NuSieveagarose 3:1 (Tébu, FMC, Rockland, ME, USA), was performed to separate the restricted fragments (restriction fragment length polymorphism, RFLP). For Ha-ras codon 12 gene mutation, when the sample was positive for the mutation (heterozygous), mutated fragments were cut out, purified and reamplified using nested-PCR primers (see above).

\section{DNA preparation and Southern blot analysis}

After electrophoresis of digested PCR products, the fragments were transferred onto nylon membranes (Hybond N, Boehringer Mannheim, Grenoble, France) according to the standard method of Southern (11): 
$10 \mu \mathrm{g}$ DNA digested with MspI, separated on 2\% agarose gel (Tébu, USA) were blotted onto nylon membranes for $3 \mathrm{~h}$ using a Vacu-Aid (Ceralabo). The filters were then hybridized with Ha-ras DNA probe that was end-labelled by the Dig Oligonucleotide 3'-End Labeling Kit (Boehringer Mannheim). The hybridization was performed at $43^{\circ} \mathrm{C}$ overnight in $5 \times \mathrm{SSC}, 2 \%$ blocking solution, $0.1 \%$ N-laurylsarcosine, and $0.02 \%$ SDS. The membranes were then washed twice in $2 \times \mathrm{SSC}, 0.1 \%$ SDS for $5 \mathrm{~min}$ and twice in $0.1 \times \mathrm{SSC}$, $0.1 \%$ SDS for $15 \mathrm{~min}$ at $43{ }^{\circ} \mathrm{C}$.

Detection was performed with the Dig Luminescent Detection Kit for Nucleic Acids (Boehringer Mannheim). Afterwards, these membranes were exposed to Kodak X-OMAT AR-5 film (Eastman Kodak, Rochester, NY, USA) for $30 \mathrm{~min}$.

\section{Direct sequencing of the mutated DNA fragment}

A gene-mutated DNA fragment comprising 108 base pairs of Ha-ras codon 12 was obtained after nested-PCR using the primers (see above) and performed in the same conditions as were used for the first PCR protocol. The PCR products were sequenced directly by the dideoxy chain termination method of Sanger et al. (12), as follows. Template DNA was denatured at $100{ }^{\circ} \mathrm{C}$ for $2 \mathrm{~min}$, annealed with $1 \mathrm{pmol}$ labelled sequencing primer, and sequenced with Sequenase PCR Product Sequencing Kit (United States Biochemical, Cleveland, $\mathrm{OH}$, USA). High-specific-activity dATP- $\left.5^{\prime}-\alpha{ }^{35} \mathrm{~S}\right]$ (sp. act. $1000 \mathrm{Ci} / \mathrm{mmol}$ ) was obtained from Amersham Corp., Arlington Heights, IL, USA. The samples were then run for $2 \mathrm{~h}$ in a $6 \%$ polyacrylamide denaturing gel (Promega Corp., Madison, WI, USA) in $1 \times$ taurine buffer (Tris base- $\mathrm{Na}_{2} \mathrm{EDTA}, 2 \mathrm{H}_{2} \mathrm{O}$-taurine), pH 8.0. After gel transfer onto $3 \mathrm{MM}$ membranes (Whatman, Maidstone, UK) and air drying by heating at $80^{\circ} \mathrm{C}$ for $45 \mathrm{~min}$, the membrane-bound samples were exposed to Kodak Biomax MR film (Eastman Kodak,) for $48 \mathrm{~h}$.

\section{Results}

Our series comprised 35 adenomas (17 atypical, 2 macrofollicular, 5 microfollicular, 7 follicular, and 4 toxic adenomas); the malignant tumours examined comprised 93 carcinomas (19 follicular, 66 papillary, and 8 undifferentiated carcinomas) (Table 1). For certain specimens, a sample was taken from a normal region of the same thyroid tissue.

Selective amplification of the region around the studied codons of the ras oncogene was performed by PCR after extraction of genomic DNA. RFLP and Southern blot analysis were then performed to detect the presence of Ha-ras codon 12 gene mutation and the DNA sequencing method was used to confirm the mutation. For purposes of interpretation of our results, we considered that, after DNA digestion, the presence of a single band of 291 bp (Fig. 1A, lane 4) was evidence of a homozygous mutation, and the presence of two bands of $236 \mathrm{bp}$ and $291 \mathrm{bp}$ was the mark of a heterozygous mutation (Fig. 1A, lanes 5 and 6). In all positive cases, we observed two bands corresponding to wild-type and mutated alleles (236 bp and $291 \mathrm{bp}$ respectively).

\section{Thyroid adenomas}

DNA of 35 benign thyroid tumours was examined. A point mutation in codon 12 of the Ha-ras gene was found in $7(20 \%)$ of them (Table 2, Fig. 1A).

Codon 12 Ha-ras gene mutation was identified in 5 atypical adenomas of the 17 tested. There were only two macrofollicular adenomas in our series and one of the two $(50 \%)$ was found to be positive for this mutation. Among the microfollicular type, one out of five tested (20\%) was found to be positive.

In our study, 30 adenomas were negative for Ha-ras codon 12 mutation after PCR-RFLP analysis, but activated Ha-ras codon 12 gene was detected in 2 more cases by the Southern blot analysis (Fig. 1B, lanes 4 and 5). Sequence analysis show that the seven observed mutations in these thyroid adenomas were $\mathrm{G}$ to $\mathrm{T}$ transversion (glycine to valine substitution; Fig. 1C). Only one codon 61 Ha-ras gene mutation was found among seven normofollicular adenomas analysed $(14.3 \%)$.

\section{Thyroid carcinomas}

We examined 93 malignant thyroid tumours. Mutations were identified in the Ha-ras codon 12 gene in 4 of $66(6 \%)$ papillary thyroid carcinomas (three in papillary carcinomas and one in papillary carcinomas with follicular differentiation), and 6 of 19 (32\%) follicular carcinomas (only in Hürthle cell carcinomas) (Table 2, Fig. 1A). We found no point mutation of the Ha-ras codon 12 in any of the undifferentiated thyroid tumours $(n=8)$.

Activated Ha-ras codon 12 was detected by the Southern blot analysis in one more case (Fig. 1B, lane 2). The analysis of mutated Ha-ras codon 12 sequences also revealed a $\mathrm{G}$ to $\mathrm{T}$ transversion (Fig. 1C). A low frequency of mutations was found in the other ras genes (Table 2): one mutation of the codon 61 Ha-ras gene among 60 papillary carcinomas $(1.7 \%)$, and two codon 12 N-ras gene mutations (one in a follicular carcinoma and the other in a papillary carcinoma).

In contrast, all normal thyroid samples showed negative results for mutation.

\section{Discussion}

Mutations in all three families of ras oncogenes have been detected in both benign and malignant thyroid 

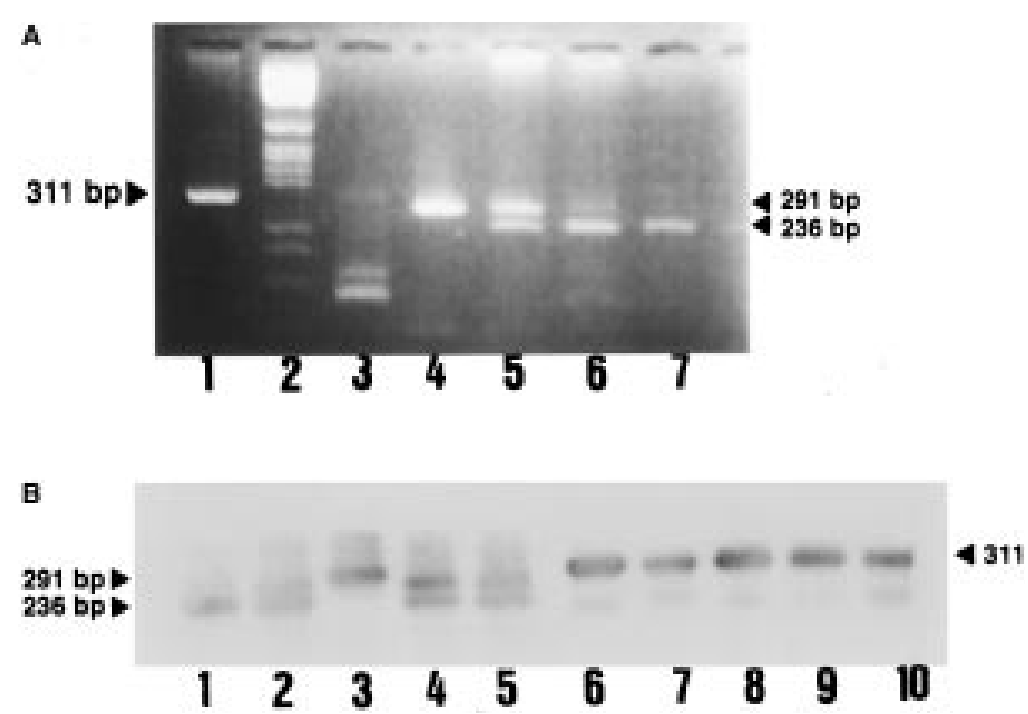

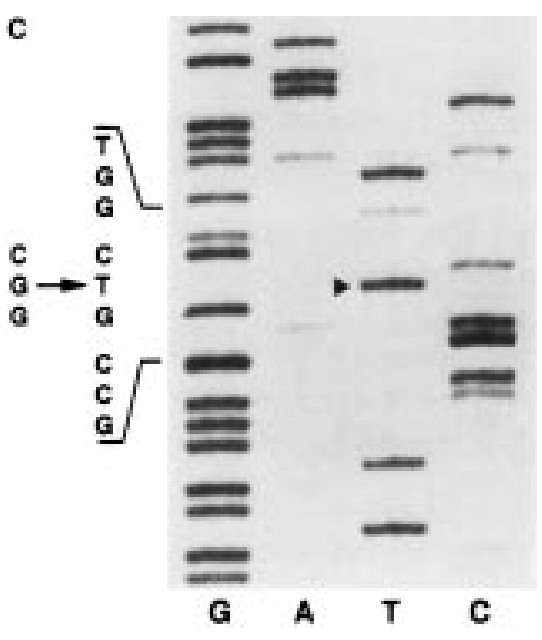

Figure 1 (A) Ha-ras codon 12 gene mutation in thyroid tumours. Lane 1: amplified non-digested fragment (311 bp); lane 2: $\Phi$ X174 Haelll digest DNA marker; lane 3: internal control (99 bp of the Ki-ras gene); lane 4: reamplified band of $291 \mathrm{bp}$ as an amplification control; lanes 5, 6: mutated DNA fragment (236-bp and 291-bp fragments), respectively from an atypical adenoma and a Hürthle cell carcinoma; lane 7: digested non-mutated fragment. (B) Southern blot hybridization technique. Mutations of the Ha-ras locus were observed in two adenomas (lanes 4, 5) and in one carcinoma (lane 2). Lane 1: normal band of $236 \mathrm{bp}$ (wild type); lanes 3, 6-10: amplified non-digested fragment (311 bp). (C) Direct sequencing performed only for the mutated DNA fragment, cut from gel electrophoresis after Mspl digestion (from Hürthle cell carcinomas). We detected a G to T transversion in the second position of codon 12 (arrowhead), responsible for a glycine-tovaline amino acid substitution.

tumours $(3-7,13-23)$. Mutations of the ras (Ha-, Ki-, $\mathrm{N}$-ras) proto-oncogene have been reported in $20-60 \%$ of thyroid tumours, particularly in follicular types $(3,5$, $6,15,17)$, and more frequently in iodine-deficient areas (16). For this reason, ras mutations have been suggested as an important pronostic marker for thyroid cancer (17).
In our study, point mutations of the Ha-ras codon 12 gene were detected by RFLP and hybridization, and positive cases were controlled by a sequencing technique. Validation of our results, and of the reliability and reproducibility of our techniques, was performed using DNA (positive for the mutation in codon 12 of the gene Ha-ras) extracted from carcinomas of the cervix (data

Table 2 Activated ras oncogenes in human thyroid adenomas and carcinomas. Values for gene and sex frequency are given as number (\%).

\begin{tabular}{|c|c|c|c|c|c|c|c|c|c|}
\hline \multirow{3}{*}{$\begin{array}{l}\text { Histological } \\
\text { type }\end{array}$} & \multirow{2}{*}{\multicolumn{2}{|c|}{$\begin{array}{l}\text { Mean age } \\
\text { (years) }\end{array}$}} & \multicolumn{5}{|c|}{ Gene frequency } & \multirow{3}{*}{$\begin{array}{l}\text { Sex } \\
\text { frequency }\end{array}$} & \multirow{3}{*}{$\begin{array}{l}\text { Amino acid } \\
\text { substitution }\end{array}$} \\
\hline & & & \multicolumn{2}{|c|}{ Ha-ras } & \multirow{2}{*}{$\frac{\mathrm{Ki} \text {-ras }}{\text { Codon } 12}$} & \multicolumn{2}{|c|}{ N-ras } & & \\
\hline & $\mathrm{F}$ & M & Codon 12 & Codon 61 & & Codon 12 & Codon 13 & & \\
\hline \multicolumn{10}{|l|}{ Adenomas } \\
\hline Atypical & 46 & 41 & $5 / 17(29.4)$ & - & - & - & - & $F(5 / 10,50)$ & GGC to GTC \\
\hline Macrofollicular & & 40 & $1 / 2(50)$ & - & - & - & - & $M(1 / 2.50)$ & GGC to GTC \\
\hline Microfollicular & 46 & & $1 / 5(20)$ & - & - & - & - & $F(1 / 5,20)$ & GGC to GTC \\
\hline Normofollicular & 42 & 35 & - & $1 / 7(14.3) \dagger$ & - & - & - & $F(1 / 6,16.7)$ & - \\
\hline Toxic & 47 & 59 & - & - & - & - & - & - & - \\
\hline \multicolumn{10}{|l|}{ Carcinomas } \\
\hline Follicular & 43 & 35 & - & - & - & $1 / 6(16.7)$ & - & $F(1 / 4,25)$ & - \\
\hline $\begin{array}{l}\text { Follicular with } \\
\text { oxyphilic cells }\end{array}$ & 45 & 56 & $6 / 11(54.6)$ & - & - & - & - & $\begin{array}{l}F(4 / 11,36) \\
M(2 / 11,18)\end{array}$ & GGC to GTC \\
\hline Follicular insular variant & 49 & 76 & - & - & - & - & - & - & - \\
\hline Papillary & 48 & 42 & $3 / 60(5)$ & $1 / 60(1.7)$ & - & $1 / 60(1 / 7)$ & - & $M(3 / 60)-M(1 / 60)$ & GGC to GTC \\
\hline $\begin{array}{l}\text { Papillary with follicular } \\
\text { differentiation }\end{array}$ & 60 & 53 & $1 / 4(25)$ & - & - & - & - & $\mathrm{M}(1 / 1,100)$ & GGC to GTC \\
\hline $\begin{array}{l}\text { Papillary and atypical } \\
\text { adenomas }^{\star}\end{array}$ & 49 & 76 & - & - & - & - & - & - & - \\
\hline
\end{tabular}

†These mutations were screened using only PCR-RFLP techniques. ${ }^{*}$ Nodule comprising an atypical adenoma and a papillary carcinoma. 
not shown). For the other ras genes, point mutations were only detected by PCR-RFLP techniques.

In our experimental conditions, when mutations affected only one allele of Ha-ras codon 12 (heterozygous) or when a homozygous cell was present among heterozygous or normal cells, both the 291- and the 236-bp DNA fragments were observed after electrophoretic migration. If only a single 291-bp fragment was observed in the tumour DNA, the mutated allele was assumed to be in a homozygous state.

In this study, we examined 128 thyroid tumours and normal tissues. None of the ten normal thyroid tissue samples had ras point mutations. However, we did not perform control experiments with $\mathrm{NIH} 3 \mathrm{~T} 3$ cells in culture conditions to establish if these DNA extracts from normal thyroid tissue are unable to induce transformation in such cells in culture, as was reported by Lemoine et al. $(4,5)$. In our series of 128 thyroid tumours, we detected a Ha-ras codon 12 point mutation in $17(16.4 \%)$ (Fig. 1A, lanes 5 and 6). ras point mutations were present in $23 \%$ of 35 thyroid adenomas, with a high frequency for atypical adenomas ( 5 of 17 , $29 \%$; Table 2), in $36.8 \%$ of 19 follicular carcinomas, and in $9 \%$ of 66 papillary carcinomas (Table 2). With our detection method, we were unable to confirm the presence of homozygous mutations.

After DNA digestion and in all positive cases, heterozygous mutated bands of 291 bp were cut from NuSieve-agarose 3:1 gel, purified and reamplified using a nested-PCR primer set. The fragment obtained after DNA reamplification was sequenced using a nested-PCR primer. The only point mutation observed was $G$ to $T$ transversion in the second nucleotide of codon 12 and was a valine for glycine substitution. We do not know the pathological significance of this substitution in thyroid tumours.

Our results suggest an association between the presence of the Ha-ras codon 12 mutation and the histological nature of adenomas. Seven positive mutations were distributed as follows: in five of seventeen atypical adenomas, in one of two macrofollicular adenomas, and one of five microfollicular adenomas. No point mutation was found in four toxic and seven normofollicular adenomas (Table 2). Our findings concerning Ha-ras codon 12 gene mutations in microfollicular adenomas (in one of five, 20\%) were intermediate compared with other published data $(4$, $5,7,15)$ (Table 3). It appears that atypical adenomas are mutated more frequently than other adenomas (toxic adenomas excluded). However, the histological identification of atypical adenomas is a difficult problem (9).

In our study of thyroid follicular carcinomas, we observed that 6 of 19 follicular carcinomas (32\%) carried the Ha-ras codon 12 gene mutation and, in all cases, the mutation was found only in follicular carcinomas with oxyphilic cells (6 of 11 such carcinomas). This mutation was identical with others found in adenomas. No point mutation was observed in six follicular and two insular carcinomas (Table 2). The number of mutations described elsewhere in the literature is more restricted and the findings vary, depending on the histological nature of the tumour studied. Lemoine et al. $(4,5)$ and Du Villard et al. (7), respectively, observed the presence of Ha-ras codon 12 gene mutation in $7 \%$ and $14 \%$ of follicular carcinomas; however, other authors $(15,17,20)$ have failed to find any Ha-ras codon 12 gene mutations in follicular carcinomas. In papillary carcinomas, Ha-ras codon 12 mutations were found in 4 of $66(6 \%)$ cases. Suarez et al. (20) and Du Villard et al. (7) found a high frequency of mutations: $50 \%$ and $44 \%$ of cases respectively, (Table 3 ), but Wright et al. (6) and Manenti et al. (13) observed no mutations in these cancers. In eight cases of undifferentiated carcinomas, we detected no point mutation of Ha-ras, in agreement with the findings of Suarez et al. (20) and Du Villard et al. (7). Lemoine et al. (5), however, observed two mutations among ten undifferentiated carcinomas.

The variation of the frequency of ras point mutations in thyroid tumours observed by different authors $(5,14$, 16) could be explained by the selection of tumours for which the histological degree of differentiation, their genetic susceptibility, or environmental factors such as dietary iodide supply (16) are different.

Ha-ras codon 12 gene mutation has been implicated in many spontaneous and experimental cancers. These mutations have been found in cancer of the bladder (24), laryngeal carcinoma (25), soft-tissue malignant fibrous histiocytomas (26), chemically induced rat mammary carcinomas (27), and bronchogenic carcinoma (28). It is of interest that thyroid tumours induced by chemical carcinogens in rats involve activation of Ha-ras (21). The role of Ha-ras codon 12 gene mutation in cell transformation has been reported by in vitro gene transfer experiments (29); this process of cell proliferation, with preservation of differentiated thyroid functions, is manifested in the phenotype of an adenoma in vivo (30).

We have also studied other ras point mutations (N-ras 12 and 13, Ha-ras 61, and Ki-ras 12). However, we have found only a low frequency of N-ras codon 12 and Haras codon 61 point mutations, in 2 papillary carcinomas from a total of $66(3 \%)$ and in 2 of 19 follicular carcinomas (11\%). No Ki-ras codon 12 gene point mutation was observed in any of the tissues we studied (Table 3). Some mutations have been detected in the Haras gene on codon 61 of thyroid tumours $(3-5,16,20$, 23). However, Ha-ras is not the only member of the ras proto-oncogene family that carries these mutations in benign and in malignant thyroid tumours: N-ras and Ki-ras gene point mutations have also been reported (3-6, 14-19, 21, 23, 31, 32). In thyroid carcinomas with oxyphilic cells, Schark et al. (19) observed a variable frequency $(4-17 \%)$ of mutation of the codon $61 \mathrm{~N}$-ras gene, depending on the stage of malignancy. 


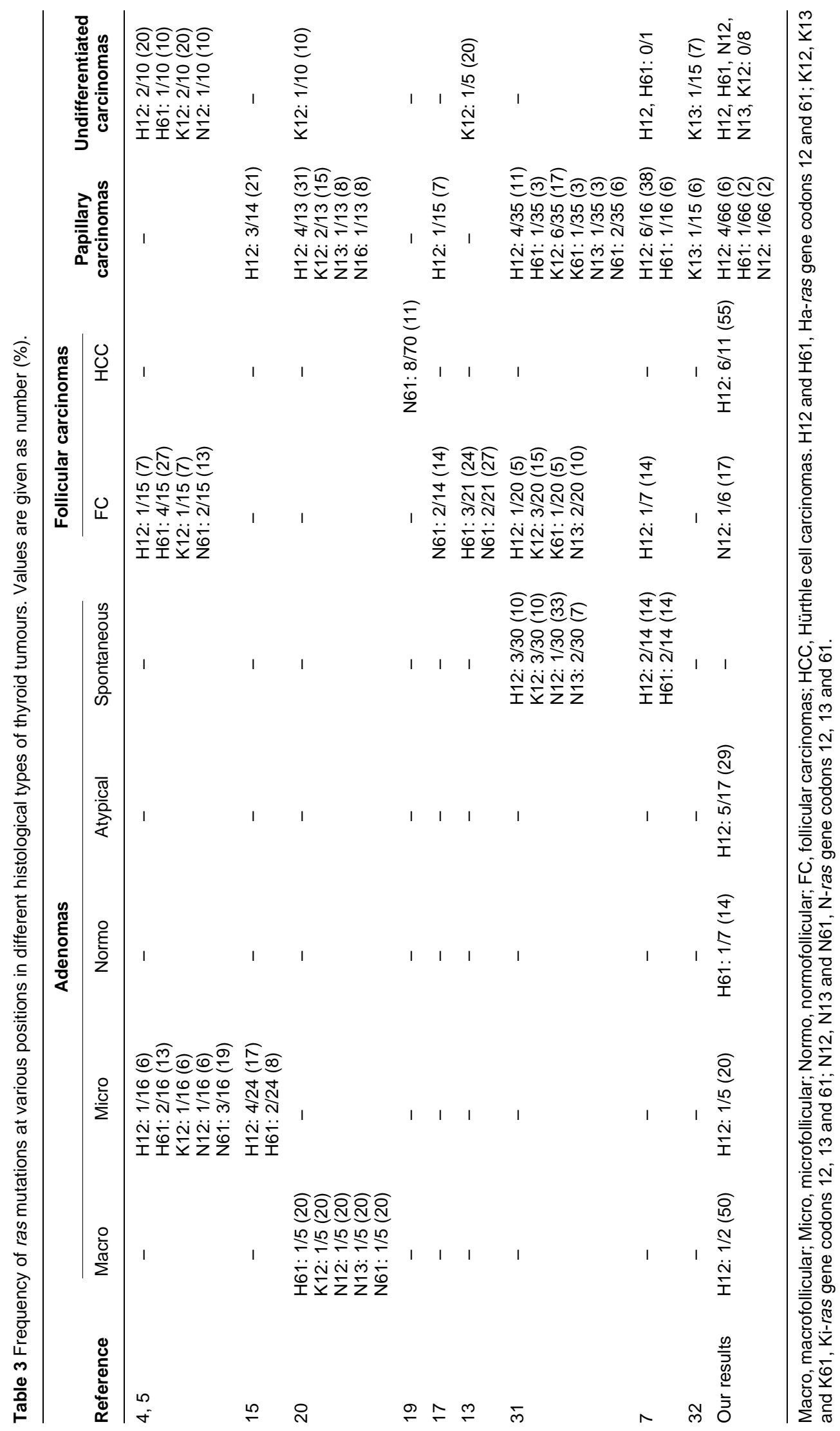


The Ha-ras codon 12 gene mutation seems to be predominant in those thyroid tumours presenting as Hürthle cells carcinomas, and to a lesser degree in atypical adenomas, and this gene mutation may be more characteristic for these two types of tumour. Other mutations involving the three ras genes are very rare, the greatest frequencies being reported by Du Villard et al. (7) and Suarez et al. (20): 38\% and 31\% respectively for the Ha-ras codon 12 gene mutations in papillary carcinomas.

Experimental data, together with the early mutation that is found in the Ha-ras codon 12 proto-oncogene in thyroid tumours, strongly suggest that this activation may constitute an initiatory event in the process of tumorigenic transformation of thyroid cells (30). Perhaps, we have found here the origin of the initiation, by Ha-ras, of Hürthle cell carcinomas, which appears first in adenomas and is conserved in carcinomas of the same origin. This would seem to justify the association, adenoma then follicular carcinoma (30). Further research on the Ha-ras codon 12 gene mutation may be valuable to the prognosis of the two forms of tumours, benign (atypical adenoma) and malignant (Hürthle cell carcinoma). Neverthless, the fact remains that the frequency of Ha-ras codon 12 gene mutation in thyroid adenomas and carcinomas varies according to the type of cancer and seems to change from one population to another.

We conclude that alterations at codon 12 of the Haras locus occur frequently in thyroid cancers and that they contribute, in association with several other oncogenes, to the transformation and progression of the cancer.

\section{Acknowledgements}

We are indebted to Messrs Saloom and Schachermayr for their critical reading of the English text. This investigation was supported by Hospices Civils de Lyon, France.

\section{References}

1 Barbacid M. Ras genes. Annual Review of Biochemistry 198756 779-827.

2 Bos JL. Ras oncogene in human cancer: a review. Cancer Research $1989494682-4689$.

3 Suarez HG, du Villard JA, Caillou B, Schlumberger M, Tubiana M, Parmentier $\mathrm{C}$ et al. Detection of activated ras oncogenes in human thyroid carcinomas. Oncogene 19882 403-406.

4 Lemoine NR, Mayall ES, Wyllie FS, Farr CJ, Hugues D, Padua RA et al. Activated ras oncogenes in human thyroid cancers. Cancer Research 198848 4459-4463.

5 Lemoine NR, Mayall ES, Wyllie FS, Williams ED, Goyns M, Stringer BM. et al. High frequency of ras oncogene activation in all stages of human thyroid tumorigenesis. Oncogene 19894 159-164.

6 Wright PA, Lemoine NR, Mayall ES, Wyllie FS, Hugues D, Williams ED et al. Papillary and follicular thyroid carcinomas show a different pattern of ras oncogene mutation. British Journal of Cancer 198960 576-577.

7 Du Villard JA, Schlumberger M, Wicker R, Caillou B, Feunteun J, Monier R et al. Role of ras and gsp oncogenes in human epithelia thyroid tumorigenesis. Journal of Endocrinological Investigation $199518124-126$.

8 Williams ED. The aetiology of thyroid tumours. Clinical Endocrinology and Metabolism 19798 193-207.

9 Hedinger $\mathrm{CH}$, Williams ED \& Sobin LH. Histological typing of thyroid tumors. In International Histological Classification of Tumors, WHO, 2nd ed. New York: Springer-Verlag, 1989.

10 Jiang W, Kahn S, Guillem J, Lu S \& Weinstein IB. Rapid detection of ras oncogenes in human tumors: applications to colon, esophageal and gastric cancer. Oncogene 19894 923-928.

11 Southern EM. Detection of specific sequences among DNA fragments separated by gel electrophoresis. Journal of Molecular Biology 197598 503-517.

12 Sanger F, Nicklen S \& Coulson AR. DNA sequencing with chain termination inhibitors. Proceedings of the National Academy of Sciences of the USA 197774 5463-5468.

13 Manenti G, Pilotti S, Re FC, Della Porta G \& Pierotti MA. Selective activation of ras oncogenes in follicular and undifferentiated thyroid carcinomas. European Journal of Cancer 1994 30A 987993.

14 Goretzki PE, Lyons J, Stacy-Phipps S, Rosenau W, Demeure M, Clark $\mathrm{OH}$ et al. Mutational activation of ras and gsp oncogenes in differentiated thyroid cancer and their biological implications. World Journal of Surgery 199216 576-581.

15 Namba H, Rubin SA \& Fagin JA. Point mutations of ras oncogenes are an early event in thyroid tumorigenesis. Molecular Endocrinology 19904 1474-1479.

16 Shi YF, Zou MJ, Schmidt H, Juhasz F, Stenszky V, Robb D et al. High rates of ras codon 61 mutation in thyroid tumors in an iodidedeficient area. Cancer Research 199151 2690-2693.

17 Karga H, Lee JK, Vickery AL, Thor A, Gaz RD \& Jameson JL. Ras oncogene mutations in benign and malignant thyroid neoplasms. Journal of Clinical Endocrinology and Metabolism 199173 832-836.

18 Dockhorn-Dworniczak B, Caspari S, Schroder S, Bocker W \& Dworniczak B. Demonstration of activated oncogenes of the ras family in human thyroid tumors using the polymerase chain reaction. Verhhandlungen Deutschen Gesellschaft für Pathologie 199074 415-418.

19 Schark C, Fulton N, Jacoby RF, Westbrook CA, Straus FH \& Kaplan EL. N-ras 61 oncogene mutations in Hürthle cell tumors. Surgery $1990108994-999$.

20 Suarez HG, du Villard JA, Severino M, Caillou B, Schlumberger M, Tubiana $\mathrm{M}$ et al. Presence of mutations in all three ras genes in human thyroid tumors. Oncogene 19905 565-570.

21 Lemoine NR, Mayall ES, Williams ED, Thurston V \& WynfordThomas D. Agent-specific ras oncogene activation in rat thyroid tumors. Oncogene 19883 541-544.

22 Boultwood J, Wyllie FS, Williams ED \& Wynford-Thomas D. N-myc expression in neoplasia of human thyroid C-cells. Cancer Research 198848 4073-4077.

23 Stringer BM, Rowson JM, Parkar MH, Seid JM, Hearn PR, Wynford-Thomas D et al. Detection of the H-ras oncogene in human thyroid anaplastic carcinomas. Experientia $198945372-376$.

24 Ramchurren N, Cooper K \& Summerhayes IC. Molecular events underlying schistosomiasis-related bladder cancer. International Journal of Cancer 199562 237-244.

25 Liu S, Lin D, Hong B \& Huang G. Analysis of c-Ha-ras gene amplification and mutation in laryngeal carcinoma. Chinese Medical Sciences Journal 199510 59-60.

26 Bohle RM, Brettreich S, Repp R, Borkhardt A, Kosmehl H \& Altmannsberger HM. Single somatic ras gene point mutation in soft tissue malignant fibrous histiocytomas. American Journal of Pathology $1996148731-738$.

27 Kito K, Kihana T, Sugita A, Murao S, Akehi S, Sato M et al. Incidence of p53 and Ha-ras gene mutations in chemically induced rat mammary carcinomas. Molecular Carcinogenesis 1996 17 78-83.

28 Wang L, Li L, Zhu Y, Fang F \& Zuo J. Proto-oncogene point mutation of c-Ha-ras in bronchogenic carcinoma. Chung Kuo I Hsueh Ko Hsueh Yuan Hsueh Pao 199517 281-285. 
29 Lemoine NR, Staddon S, Bond J, Wyllie FS, Shaw JJ \& WynfordThomas D. Partial transformation of human thyroid epithelia cells of mutant Ha-ras oncogene. Oncogene 19905 1833-1837. 30 Wynford-Thomas D. Molecular genetics of thyroid cancer. Trends in Endocrinology and Metabolism 19934 224-232.

31 Challeton C, Bounacer A, Du Villard JA, Caillou B, De Vathaire F, Monier $\mathrm{R}$ et al. Pattern of ras and gsp oncogene mutations in radiation-associated human thyroid tumors. Oncogene 199511 601-603.
32 Salvatore D, Celetti A, Fabien N, Paulin C, Martelli ML, Battaglia C et al. Low frequency of p53 mutations in human thyroid tumors; p53 and ras mutation in two out of fifty-six thyroid tumors. European Journal of Endocrinology 1996134 177-183.

Received 15 January 1998

Accepted 7 April 1998 